\title{
Teacher Professionalism on the Developing Children Creativity (Sociology of Education Perspective)
}

\author{
Ummi Nurul Muslimah \\ SMP Negeri 5 Sragen \\ JI. Mawar No. 4 Sragen 57212, Central Java-Indonesia \\ ummi.nurul_m@yahoo.com
}

\begin{abstract}
This research is to study the concept of teachers' professionalism and children creativity also the relation in sociology of educational perspective. This is a library research with a descriptive method. The writer collected the data from the writing sources published about some problems of teacher's professionalism on the developing children creativity. Then, analyzing the thinking of every ideology and philosophy described clearly and completely, so the similarity and differences can be treated clearly by using the description of teacher professionalism on developing children creativity. The findings of this study showed that the relation between teacher professionalism and developing children creativity in sociology of education is every educator have an important role in children education, although in teaching learning process or in out class, educators have always supported and challenged abilities of the gift, talent and creativity. The reason is because the children are more often spend much time with teacher, so the teacher more to know and more responsible to their children.
\end{abstract}

Keywords: Teachers' Professionalism, Children Creativity, Sociology of Educational Perspective

\begin{abstract}
Abstrak
Penelitian ini bertujuan untuk mendalami konsep profesionalisme guru dan kreativitas anak, hubungannya dengan sosiologi dari perspektif edukasi. Berbasis pada studi pustaka dan metode deskriptif, peneliti mengumpulkan data dari sumber-sumber tertulis yang memaparkan tentang profesionalisem guru dalam mengembangkan kreativitas anak. Selanjutnya, pemikiran setiap ideology dan filosofi dianalisis secara jelas dan lengkap, sehingga kesamaan maupun perbedaan dapat dilihat sejara jelas. Temuan dari studi ini
\end{abstract}

REGISTER, VOL. 2, No. 1, JUNE 2009 
menunjukkan bahwa hubungan antara profesionalisme guru dan pengembangan kreativitas anak dalam ranah sosiologi pendidikan terletak pada kesimpulan bahwa pendidik memiliki peran penting dalam pendidikan anak. Baik dalam proses belajar mengajar atau di luar kelas. Pendidik harus selalu mendukung dan mengembagkan kemampuan, karunia, talenta, dan kreativitas anak. Hal ini dikarenakan anak lebih banyak menghabiskan waktu bersama guru sehingga guru tentunya mengetahui lebih banyak dan memiliki tanggung jawab yang lebih terhadap anak didik mereka.

\section{Kata Kunci: Profesionalisme Guru, Kreativitas Anak, Sosiologi dari Perspektif Pendidikan}

\section{Introduction}

The wide society of developing countries needs superior orientation in the world of education to increase human resources quality and competitive future among nations. In the micro perspective, education is the one of communities, which consists of teachers and students to eduction identity in the school context itself. Generally, the education funtions are to maintain and to develop human character or disposition and their skill and their ability, to make them to be the perfect human, having value and degree.

The education always requires teaching, but not all teaching is education. Educational cases are conceit of teachers who always have an important role $\mathrm{n}$ educational process. One assumption said that the teacher influences teaching and learning process. Therefore, the teacher should have a good ability and skill to teach.

It is widely recognized that 85 percent of job failures attributable to inadequacies in human relationship. As stated in other way, inability to be along with fellow workers is a much more frequent cause of failure thatn lack of technical proficiency. So that some teachers should be encouraged to promote themselves as professionals person, and should grow to become 
more open, more human, more skillful more complex, more complete pedagogues, and more critical to their children or students.

It is serious to talk about teacher professionalism on the developing children creativity in the sociology of education perspective. Because it is used to solve the education issues itself. Furthermore, the basic problem in sociology of education situation is the social relationship, between teacher and student, by the way totality this relation is called family unit is the school family.

From this point of view, indeed, it is arguably important for the writer to make a research about the teacher and the children in sociological of education perspective. The problem investigated in this study is teacher professionalism on the developing children creativity from sociological of education perspective, as the following; (1) how is the concept of teachers' professionalism from sociological of education perspective? (2) how is the concept of children creativity from sociological of education perspective? (3) how is the relation between teacher professionalism and developing children creativity in sociology of educational concept?

\section{Professionalism}

In dictionary, 'professional' means skillful (Shadily, 1976:449). However, the other opinion says, profession is a position or a job which needs a certain skill (Uzer, 1990:4). He says, profession is occupation; example one requiring advanced edcuation and special training. Professional is the concept of teaching that must be done an expert. A professional is a person who has competency, because competency is very important to perform the professional function.

To be professonal, teachers must try to obtain the following character traits; she must absolutely understand their students, she must fulfill their 
obligation to the community, she must be honest and fair, she must have pure motives and must be an example to their students, she must have a broad understanding, she must possess a good timing, she must be enthusiastic and must be phsycally healthy (Sriyono, 1991:75).

Teacher has an important role in education. Nowadays education does not view a teacher as the only scientific and information agents, as teachers, but technological equipment of data saving and any others do not only master those two matters. In this global era, a teacher is more viewed as a facilitator, a guide, or an information agent who organizes teaching and learning process. Every teacher has many role such as and observer, manager, facilitator, counselor, and instructor in the common procedure of teaching.

\section{The Profession of Teacher on Sociological Education}

As long as 1915 Abram Flexer submitted the following criteria for a profession. "It could be learned in character, practical and definite in purpose, possessed of a technique capable of being transmitted through an orderly and highly specialized educational discipline, and organized into brotherhood with increasing elements of altruistic motivation." Since that times other definitions for a profession have been set forth, but most of them list substantially these same attributes.

Almost all definitions of a profession include the following criteria; the performance of a service to the public, the possession of unique body of scientific knowledge and technical skill, the requirement of highly specialized and usually formal preparations, the regulation of standards for the admission to practice by members of profession and the organization of practitioners into comprehensive to conduct and ethics (Gibson, 1992:40).

We believe that the quality of the services of the education profession directly influences the future of the nation and its citizen. We therefore exert 
every effort to raise educational standards, to improve the service, to promote a climate in which the exercise of professional judgement is encouraged, and to achieve conditions which attract persons worthy of the trust to careers in education.

\section{Children Creativity}

God is the only creator; human being cannot create anything new. Creativity, as we use the term, means seeing orexpressing new relationship among anything's idea. Every child is creative and its dimensions vary from individual to individual. Creative children are asserts to the society. Development and progress in various fields of national life depends on creative children. We must tryto develop creativity in all children so that the way exert in their fields of interest and can lead the nation a head. Our school children to prepare leaders in different walks of national life. The school should screen creative children and should provide them all possible facilities for the development of their talents.

Creativity is an important aspect of a person's existence. It gives flavour to ones life. That is why it is crucial to teach a child how to enhance her creativity and to draw upon it for inspiration. Creativity is also enhanching the quality of solutions to life's problem. Creative thinking examples, it results in original solutions to problem that continually arise in the personal and vocational spheres. Creativity is important because it predicts life achievement better than more conventional and widely used predictors such as scores on measures of general intelligence and standardized achievement test on school grades.

REGISTER, VOL. 2, No. 1, JUNE 2009 


\section{Research methodology}

This research is descriptive where the writer attempts to collect the data from the library, as the data sources.

1. Method of Collecting Data; to collect the data about some problems of teacher's professionalism on the developing children creativity, she uses library research to study the writing sources published.

a. Primary data sources; it is the source data related to the object of the research. The primary source is essential derived from books "Sociology of Education perspective"

b. Secondary data sources; the secondary data is the data source, which supports and completes the primary data, example: books about teacher professionalism, development of children and social education.

2. The method of Analyzing data

a. Descriptive method; means the thinking of every ideology and philosophy described clearly and completely, so the similarity and differences can be treated clearly too, using this description of teacher professionalism on the developing children creativity.

b. This is still a general description, so, to understand this thesisi easily, the writer uses the books, which are appropriate with the research. It means, on processing, collecting, and analyzing data, the writer looks for books, which relate to the research, collect and regard them as the first information.

\section{Discussion}

The professionalism is a subject of interest to academic the general public and would be professional groups. Traditional ideas of professions and 
professional conduct have been chalenged by recent social, political and technological changes.

\section{The Professional Qualification of the Teacher}

How do we think of ourselves professional teacher? Everybody knows that to be the professional teacher is not so easy. Because the criteria to be professional, teachers must try to obtain the following character traits; the teacher must as a parent to their students, she must absolutely understand their students, she must absolutely understand their student, she must fulfill their obligation to the community; the teacher must be honest and fair, the teacher must have pure motives must be an example to their students; the teacher must have understanding; the teacher must posses good timing, she must be enthusiastic and also must be phsycally healthy (Sriyono, 1991:75)

From the criteria above to be the professional teacher is not so simple, because the teacher must pay attention with the student not just in the class but also in the out class. According to Marsal and Bruice say that the teacher contact with the students is formal: they are assembled in class to take one or more courses from us and he has informal contact also with them as well (Weil, 1978:1). It means that the teachers must be available in the school; class teacher and the non-class teacher. If the class teacher should teach English or the other subject, she or he should be given special in service training. This cannot be done easily. In addition, teaching-learning process needs much time and any attention. If the non class, she or he does not do teaching-learning process some subjects or English teacher just relax without playing any attention to their students. From that explanation we can know that the role of teacher is not so easy.

The teacher plays important roles in the teaching-learning process. The qualification of a professional teacher should has certain competence and 
ability to be a qualified teacher. We have known that the children still easy to be influenced to the other things. They dependent to their teacher, their friend and also their family in making their decission. That is why the professional teacher should try to work and understand each characteristic of students. In the class the teacher is responsible for many types of instruction, for helping the children creativity and in this ability to relate others.

In teaching-learning process, the teacher roles is for giving motivation of any classroom activity, guide and give facility to study their children, so teaching. Every learning-teaching process in the classroom, the teacher will contact directly in extended periods with his own pupils. The teacher normally has some direct contact, but who may also have considerable indirect influence upon him during teaching-learning in the class. Finally, the teacher's contacts with groups and individual beyond the school tend be occasional and tenuos; but they too may expert powerful influences on him indirect ways.

\section{Developing children creativity}

We have known that the creativity is the important thing in our life, more ever for the children. Because children is the active age for do everything. For example, that when the children want to make broke their toy, and they want to repair that toy by their self, or for the girls sometimes they want help their mother in the kitchen and disturb her mother. It is one form of creative activity for the children.

Actually, creativity is difficult concept to define. It may mean the use of such process as divergent thinking-thinking in unconventional directions. It may mean the ability to generate different ideas to think of alternate uses for familiar objects and alternative solutions the problem. Creative process, however, can only be understood by means of their and results the actual 
ideas, productions, and solutions that are developed, whether a particular products is indeed "creative" or "original" requires social judgement, which is subject to error. Creativity thus always has a social, as well as an individual dimensions.

\section{The Relation of the Teacher Professionalism on Developing Children}

\section{Creativity}

From explanation about the professionalism and the children creativity above the writer can take a statement that there is correlation or there is relation between the teacher professional on developing children activity. If the teacher professional to manage their time in the class and make the lesson more interest, they can develop the children creativity.

Creative depends not only on special inborn potentials but also on differences in the mental mechanisms by which the inborn qualifies in the mental mechanisms by which the inborn qualities are expressed (Hurlock, 1978:330). Actually every people have the same quality but just creative and noncreative persons make use of similar and different mental mechanisms. Creative and noncreative person differ in the attitude, what they hold important and what is anxiety-producing and show differences in problem solving skills. These differences originate partially in born rooted in parental attitudes.

The relation of teacher professional on developing children creativity is so close, because is the teacher professional to do their job so the children creativity is not run well. Every educator have important role children education, although in teaching learning process or in out class, educators have always supported and challenged abilities of the gifted, talented and creativity. The reason is because the children are often spend many times 
with the teacher, so the teacher more to know and more responsible to their children.

So that all teacher must be a more skillful, capable and must be a professional, the implication what is kind developing children creativity. The reason is because the teacher professionalism is understood with the children the talented, so they will posit when will forced, arranged and give a freedom to their children. Therefore, the children developing creativity will run well.

The good teacher can facilitate to their children or the student on developing their creativity, because the teacher is the second parent in the school. Thus, in school the teacher must cooperate with the student to develop their creativity. In modern era creativity is so important, because everything is so luxury and expensive. Beside that we must make competition with the people to get it. Therefore, the teacher must give the good strategies to more creative and can survive our life in this era.

\section{Conclusion}

In conclusion, this study finally found that the concept of teachers; professionalism from sociological education perspective is teacher as educator is a man responsible on the learners development by striving potentials development affectivity, cognitively and pshychomotorically. They also must be able to fulfill their duty weather as divine individual or social creatures. Furthermore, the concept of children creativity from sociological education perspective is a process of becoming sensitive to problems, deficiency, gasps and soon. Identifying the difficulties and searching for solutions. Children creativity is asset to the society. Development and progress in various fields of national life depends on creative children. We must try to develop creativity in all children. Eventually, the relation between 
teacher professionalism and developing children creativity in sociology of education is every educator have an important role in children education, although in teaching learning process or in out class, educators have always supported and challenged abilities of the gift, talent and creativity. The reason is because the children are more often spend many time with teacher, so the teacher more to know and more responsible to their children.

\section{References}

Ahmadi, Abu Drs. 1990. Sociology Pendidikan. Bandung: Rineka Cipta.

Carr, David. 2000. Professionalism and Ethics in Teaching. New York: Rotledge.

Gibson, Dorothy Westby. 1992. Social Perspectives on Education and the Society, the student, the school.San Fransisco: The Odyssey Press, NCC.

Hurlock, Elizabeth. 1978. Children Development. Mc Graw-Hill Book Company.

Runco, Mark A., and Robert S. Albert. 1990. Theories of Creativity. New Delhi: Sage Publications, Newbury Park London.

Shadily, Hasan and John M. Echolis. 1976. Kamus Inggris Indonesia. Jakarta: PT Gramedia

Sriyono dkk. 1991. Teknik Belajar dalam CBSA. Jakarta: Rineka Cipta.

Uzer Usman, Muhammad. 1990. Menjadi Guru Profesional. Bandung: Remaja Rosdakarya.

Zamroni, M.A. 2001. Pendidikan untuk Demokrasi Tantangan Menjadi Civil Society. Yogyakarta: Bigra.

REGISTER, VOL. 2, No. 1, JUNE 2009 